\title{
PENGARUH KARAKTERISTIK PEMERINTAH DAERAH, KOMPLEKSITAS PEMERINTAHAN DAN KEMANDIRIAN KEUANGAN DAERAH TERHADAP KINERJA FISKALKABUPATEN/KOTA DI JAWA TENGAH
}

\author{
Nuwun Priyono ${ }^{1}$, Siti Arifah $^{2}$, Eva Wulandari ${ }^{3}$ \\ Email: nuwunpriyono@untidar.ac.id ${ }^{1}$, sitiarifah@untidar.ac.id ${ }^{2}$, eva_wulandari@untidar.ac.id ${ }^{3}$ \\ ${ }^{1,2,3)}$ Fakultas Ekonomi, Universitas Tidar
}

\begin{abstract}
Abstrak
Kinerja fiskal pemerintah daerah merupakan sebuah tuntutan yang harus dipenuhi dalam rangka mempertanggungjawabkan pengelolaan keuangan daerah pada era otonomi. Semakin transparan dan akuntabel sebuah laporan keuangan yang diterbitkan oleh pemerintah daerah mencerminkan bahwa kinerja fiskal akan semakin baik. Kinerja fiskal yang baik akan berpengaruh langsung bagi peningkatan kesejahteraan dan kemakmuran masyarakat. Tujuan penelitian ini: 1) menganalisis dan membuktikan faktor karakteristik pemerintah daerah berpengaruh terhadap kinerja fiskal pemerintah Kabupaten/Kota di Propinsi Jawa Tengah, 2) menganalisis dan membuktikan faktor kompleksitas pemerintahan berpengaruh terhadap kinerja fiskal pemerintah Kabupaten/Kota di Propinsi Jawa Tengah, 3) menganalisis dan membuktikan faktor kemandirian keuangan daerah berpengaruh terhadap kinerja fiskal pemerintah Kabupaten/Kota di Propinsi Jawa Tengah. Luaran penelitian ini dapat menghasilkan naskah yang dikirim pada jurnal nasional tidak terakreditasi dan materi yang dapat digunakan sebagai pengayaan bahan ajar pada mata kuliah akuntansi sektor publik.

Data yang digunakan dalam penelitian ini adalah data sekunder. Data laporan neraca dan data laporan realisasi APBD berasal dari direktorat jenderal perimbangan keuangan. Data jumlah SKPD dan jumlah penduduk diperoleh dari kantor Badan Pusat Statistik dan Pemerintah Propinsi Jawa Tengah. Penelitian ini menggunakan data time series yaitu data tahun 2010 sampai dengan 2012. Teknik pengambilan sampel menggunakan purposive sampling yaitu teknik penentuan sampel dengan pertimbangan tertentu. Metode penelitian yang digunakan adalah penelitian kausalitas dengan model regresi linear berganda.Hasil uji t dalam penelitian ini adalah hanya variabel Kekayaan Daerah $\left(\mathrm{X}_{2}\right)$ dan Jumlah Penduduk $\left(\mathrm{X}_{4}\right)$ yang secara parsial berpengaruh terhadap Kinerja Fiskal (KF). Sedangkan hasil uji F menunjukkan bahwa variabel Ukuran Pemda $\left(\mathrm{X}_{1}\right)$, Kekayaan Daerah $\left(\mathrm{X}_{2}\right)$, Tingkat Ketergantungan $\left(\mathrm{X}_{3}\right)$, Jumlah Penduduk $\left(\mathrm{X}_{4}\right)$, Jumlah SKPD $\left(\mathrm{X}_{5}\right)$, dan Kemandirian Keuangan Daerah $\left(\mathrm{X}_{6}\right)$ secara bersama sama berpengaruh terhadap Kinerja Fiskal (KF).
\end{abstract}

Kata Kunci: Karakteristik Pemerintah Daerah, Kompleksitas Pemerintahan, Kemandirian Keuangan Daerah, Kinerja Fiskal

\section{Pendahuluan}

Sejarah reformasi keuangan negara dan keuangan daerah di Indonesia sudah melewati beberapa fase. Fase pertama adalah era pra-reformasi yaitu ditandai dengan adanya UU No. 5 Tahun 1974 dan PP No. 5 dan 6 Tahun 1976. Dalam fase ini juga ditandai dengan adanya Manual Administrasi Keuangan Daerah (MAKUDA) Tahun 1980. Kemudian fase selanjutnya merupakan fase era transisi. Dalam fase ini ditandai dengan adanya UU No. 22 dan 25 Tahun 1999 yang merupakan UU yang manjadi dasar bagi pelaksanaan otonomi daerah. Selanjutnya fase era pascatransisi yaitu fase yang merupakan tonggak reformasi keuangan negara dan daerah. Dalam era ini telah disahkannya tiga paket undang-undang yaitu: UU No 17 Tahun
2003 tentang keuangan negara, UU No. 1 Tahun 2004 tentang perbendaharaan negara dan UU No. 15 Tahun 2005 tentang pemeriksaan pengelolaan dan tanggungjawab keuangan negara.Menurut Mahmudi (2011) ${ }^{[1]}$ ketiga paket undangundang tersebut memberikan penjelasan tentang prinsip dasar pengelolaan keuangan negara meliputi baik asas-asas yang telah lama dikenal dalam pengelolaan keuangan negara, seperti asas tahunan, asas universalitas, asas kesatuan, dan asas spesialitas maupun asas-asas baru sebagai pencerminan best practices(penerapan kaidah-kaidah yang baik) dalam pengelolaan keuangan negara.

Penerapan kaidah-kaidah yang baik tersebut telah mendorong penyelenggara pemerintah baik pemerintah pusat maupun 
pemerintah daerah melakukan transparansi dalam pengelolaan keuangan negara yang tercermin dari penyusunan laporan keuangan yang transparan dan akuntabel. Penyusunan laporan keuangan bagi pemerintah pada era reformasi keuangan negara merupakan hal yang wajib dilakukan. Laporan keuangan yang disusun oleh pemerintah, khususnya pemerintah daerah merupakan alat yang digunakan sebagai salah satu pengukuran kinerja pemerintah. Kinerja fiskal pemerintah daerah akan dapat diukur ketika pemerintah daerah dapat menyusun laporan keuangan daerah yang akuntabel.

Pada era otonomi, pemerintah daerah telah diberikan kewenangan yang luas dalam pengelolaan keuangan daerahnya yang digunakan sebesar-besarnya untuk kemakmuran dan kesejahteraan masyarakat. Pemerintah diberikan kewenangan dalam menjalankan kebijakan desentralisasi fiskal. Daerah mempunyai peluang untuk menggali dan meningkatkan Pendapatan Asli Daerah (PAD). Disamping mendapatkan PAD, pemerintah daerah juga mendapatkan dana transfer yang merupakan dana perimbangan dari pemerintah pusat, yang berupa: dana bagi hasil, dana alokasi khusus dan dana alokasi umum.

Selain potensi keuangan yang dimiliki tersebut, pemerintah daerah juga mempunyai kondisi internal seperti: karakteristik pemerintah daerah dan kompleksitas pemerintah daerah tersebut. Kedua faktor tersebut langsung atau tidak langsung akan memberikan pengaruh bagi pengelolaan keuangan daerah, yang tercermin dari laporan keuangan. Kemudian kemandirian keuangan daerah yang mencerminkan seberapa kuat daerah mampu mengurangi ketergantungan dari pemerintah pusat juga akan memberikan warna bagi pengelolaan keuangan daerah.

Berdasarkan uraian latar belakang di atas, penelitian ini merumuskan permasalahan mengenaipengaruhfaktorfaktor seperti: karakteristik pemerintah daerah, kompleksitas pemerintahan dan kemandirian keuangan daerah terhadap kinerja fiscal Kabupaten/Kota yang ada di Propinsi Jawa Tengah. Tujuan penelitian ini adalah: membuktikan seberapa besar faktor- faktor seperti: karakteristik pemerintah daerah,kompleksitaspemerintahandankeman dirian keuangan daerah berpengaruh terhadap kinerja fiskal Kabupaten/Kota yang ada di Propinsi Jawa Tengah. Sedangkan luaran penelitian ini adalah: 1) menghasilkan naskah dimasukan pada jurnal nasional tidak terakreditasi, 2). Menghasilkan materi yang digunakan sebagai pengayaan bahan ajar pada mata kuliah Akuntansi Sektor Publik.

\section{Metode Penelitian}

A. Waktu dan Tempat Penelitian

Waktu penelitian ini selama dua belas bulan terhitung mulai dari penandatangan kontrak penelitian dengan Lembaga Penelitian dan Pengabdian (LPPMPMP) Universitas Tidar pada bulan Januari 2015 sampai dengan 31 Desember 2015. Sedangkan tempat penelitian ini di Magelang (pengolahan data dan pelaporan).

\section{B. Sumber Data}

Penelitian ini menggunakan jenis data sekunder dengan menggunakan data time series yaitu periode tahun 2010-2012. Adapun data yang diperoleh yaitu berupa data laporan neraca dan realisasi penerimaan anggaran pendapatan belanja daerah (APBD) dari Direktorat Jenderal Perimbangan Keuangan Kementerian Keuangan RI. Dari laporan neraca diperoleh data mengenai jumlah aset total. Sedangkan dari data realisasi anggaran ini diperoleh data mengenai, Pendapatan Asli Daerah (PAD), Dana Bagi Hasil (DBH), dan Dana Alokasi Umum (DAU). Selain itu juga diperoleh data mengenai jumlah surplus atau defisit, jumlah pendapatan total dan jumlah dana transfer total. Sedangkan data mengenai jumlah penduduk diperoleh dari Badan Pusat Statistik (BPS) melalui internet. Sedangkan data jumlah SKPD (Satuan Kerja Perangkat Daerah) diperoleh secara langsung dari Biro Organisasi dan Kepegawaian Sekretariat Daerah Propinsi Jawa Tengah. Data jumlah SKPD pada Kabupaten/Kota di Jawa Tengah yang diperoleh adalah data yang dikeluarkan oleh Biro Orpeg Setda Propinsi Jawa Tengah Tahun 2013. Karena keterbatasan 
data penelitian maka data jumlah SKPD Tahun 2013 ini mengasumsikan bahwa Tahun 2010-2012 tidak terdapat penambahan atau pengurangan jumlah SKPD.Teknik pengambilan sampel menggunakan purposive sampling yaitu teknik penentuan sampel dengan pertimbangan tertentu (Sugiyono, 2003) $)^{[12]}$.

\section{Pelaksanaan Penelitian}

Dalam penelitian ini, metode pengumpulan data yang dipakai adalah melalui studi pustaka yang merupakan teknik untuk mendapatkan informasi melalui catatan, literatur, dokumentasi yang masih relevan dalam penelitian ini. Selain itu data juga diunduh melalui internet dan didapat langsung dari kantor/instansi yang berkaitan dalam penelitian ini. Data mengenai jumlah SKPD didapat secara langsung dari Biro Organisasi dan Kepegawaian Setda Propinsi Jawa Tengah dan jumlah penduduk didapat dari BPS Propinsi Jawa Tengah melalui internet. Data laporan neraca dan laporan realisasi APBD didapat dari Direktorat jenderal perimbangan keuangan kementerian keuangan RI. Selain itu data diperoleh melalui website berikut ini: www.djpk.kemenkeu.go.id,dan www.bps.go.id.

D. Indikator Yang Diamati

Indikator atau variabel yang diamati dalam penelitian ini adalah variabel dependen dan variabel independen. Variabel dependen dalam penelitian ini adalah kinerja fiskal pemerintah daerah yang akan diukur dengan menghitung nilai surplus/defisit anggaran yaitu realisasi total pendapatn dikurangi realisasi total belanja (Halim, 2007) $)^{[11]}$. Sedangkan variabel independennya adalah karakteristik pemerintah daerah yang meliputi: ukuran pemda, kekayaan daerah dan tingkat ketergantungan. Ukuran pemda dapat dilihat dari besarnya total aset, dinyatakan dalam angka. Kekayaan daerah dihitung dengan membandingkan rasio antara total pendapatan dengan jumlah penduduk, dinyatakan dalam angka. Tingkat ketergantungan diukur dengan menghitung rasio antara total dana transfer dibagi dengan total pendapatan, dinyatakan dengan persentase. Variabel independen yang lainnya adalah kompleksitas pemerintah daerah dan kemandirian keuangan daerah. Kompleksitas pemerintah daerah terdiri dari jumlah penduduk dan jumlah SKPD yang ada di Kabupaten/kota di Jawa Tengah. Jumlah penduduk dan jumlah SKPD dinyatakan dalam satuan angka. Sedangkan kemandirian keuangan daerah dihitung dengan menggunakan rasio kemandirian yang merupakan rasio antara PAD dibandingkan dengan bantuan pemerintah pusat/propinsi ditambah dengan pinjaman, dinyatakan dengan persentase.

E. Model Penelitian

Pengujian hipotesis dilakukan dengan menggunakan model analisis regresi berganda, bertujuan untuk memprediksi kekuatan pengaruh seberapa besar variabel independen terhadap variabel dependen. Teknik yang digunakan dalam analisis regresi ini dengan menggunakan metode kuadrat terkecil/ ordinary least squares (Gujarati, 2003) ${ }^{[13]}$. Persamaan regresinya adalah :

$\mathrm{KF}=\alpha+\boldsymbol{B}_{1} \mathbf{X}_{1}+\boldsymbol{B}_{2} \mathbf{X}_{2}+\boldsymbol{B}_{3} \mathbf{X}_{3}+\boldsymbol{B}_{4} \mathrm{X}_{4}+$ $B_{5} X_{5}+B_{6} X_{6}+e$

dimana : KF = Kinerja Fiskal, $\alpha=$ Konstanta, $\beta=$ Slope atau koefisien regresi atau intersep, $\mathrm{X}_{1}=$ Ukuran Pemda, $\mathrm{X}_{2}=$ Kekayaan Daerah, $\mathrm{X}_{3}=$ Tingkat Ketergantungan, $\mathrm{X}_{4}=$ Jumlah Penduduk, $\mathrm{X}_{5}=$ Jumlah SKPD, $\mathrm{X}_{6}=$ Kemandirian Keuangan Daerah, $e=$ error.

Selain itu menggunakan uji asumsi klasik seperti: uji normalitas, multi kolinieritas, uji heterokesdasitas, uji auto korelasi sebelum data diolah kedalam regresi linier.

\section{Hasil Dan Pembahasan}

A. Analisis Regresi Linier Berganda

Setelah dilakukan uji asumsi klasik, model regresi linier tidak ditemukan masalah dalam normalitas, multikolinieritas, autokorelasi, dan heterokesdasitas. Dengan hasil pengujian asumsi klasik tersebut berarti model regresi liniear layak untuk dilakukan pengujian lebih lanjut yaitu pengujian secarasi multan dan parsial (Ghozali, 2006) ${ }^{[14]}$. Pengujian secarasi multan denga nmenggunakan uji $F$, 
sedangkanp engujian secara parsial dengan menggunakan uji t.

Adapun hasil output regresi linier berganda menggunakan SPSS versi. 16 adalah sebagai berikut:

Tabel 1. Model Summary

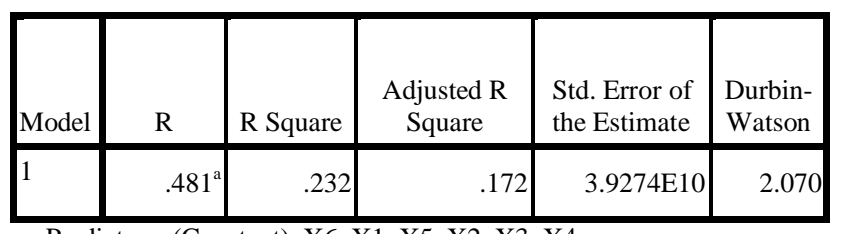

a. Predictors: (Constant), X6, X1, X5, X2, X3, X4

b. Dependent Variable: Y

1) KoefisienDeterminasi

Koefisien determinasi $\left(\mathrm{R}^{2}\right)$ pada intinya mengukur seberapa jauh kemampuan model dalam menerangkan variasi variabel dependen. Nilai koefisien determinasi adalah antara nol dan satu. Dalam tabel 1. diatas menunjukkan besarnya adjusted $\mathrm{R}^{2}$ adalah 0,172 atau $17,2 \%$. Hal ini berarti bahwa variabel dependen Kinerja Fiskal (KF) dipengaruhi oleh variabel Ukuran Pemda $\left(\mathrm{X}_{1}\right)$,Kekayaan Daerah $\left(\mathrm{X}_{2}\right)$, Tingkat Ketergantungan $\left(\mathrm{X}_{3}\right)$, Jumlah Penduduk $\left(\mathrm{X}_{4}\right)$, Jumlah SKPD $\left(\mathrm{X}_{5}\right)$, Kemandirian Keuangan Daerah $\left(\mathrm{X}_{6}\right)$ sebesar $17,2 \%$, sedangkan sebesar $82,8 \%$ dipengaruhi oleh variabel-variabel lain selain keenam variabel independen tersebut.

2) PengujianParsial (UjiStatistik t)

Uji statistik $t$ pada dasarnya menunjukkan seberapa jauh pengaruh satu variabel independensecara individual /parsial dalam menerangkan variasi variable dependen (Ghozali, 2006) ${ }^{[14]}$. Hipotesisnol (Ho) yang hendak diuji adalah apakah suatu parameter (bi) sama dengan nol, atau:Ho:bi=0 Hipotesisal ternatifnya (HA) parameter suatu variable tidak sama dengan nol, atau:HA:bi $\neq 0$
Tabel 2. Hasil Uji Signifikansi $t^{\mathrm{a}}$

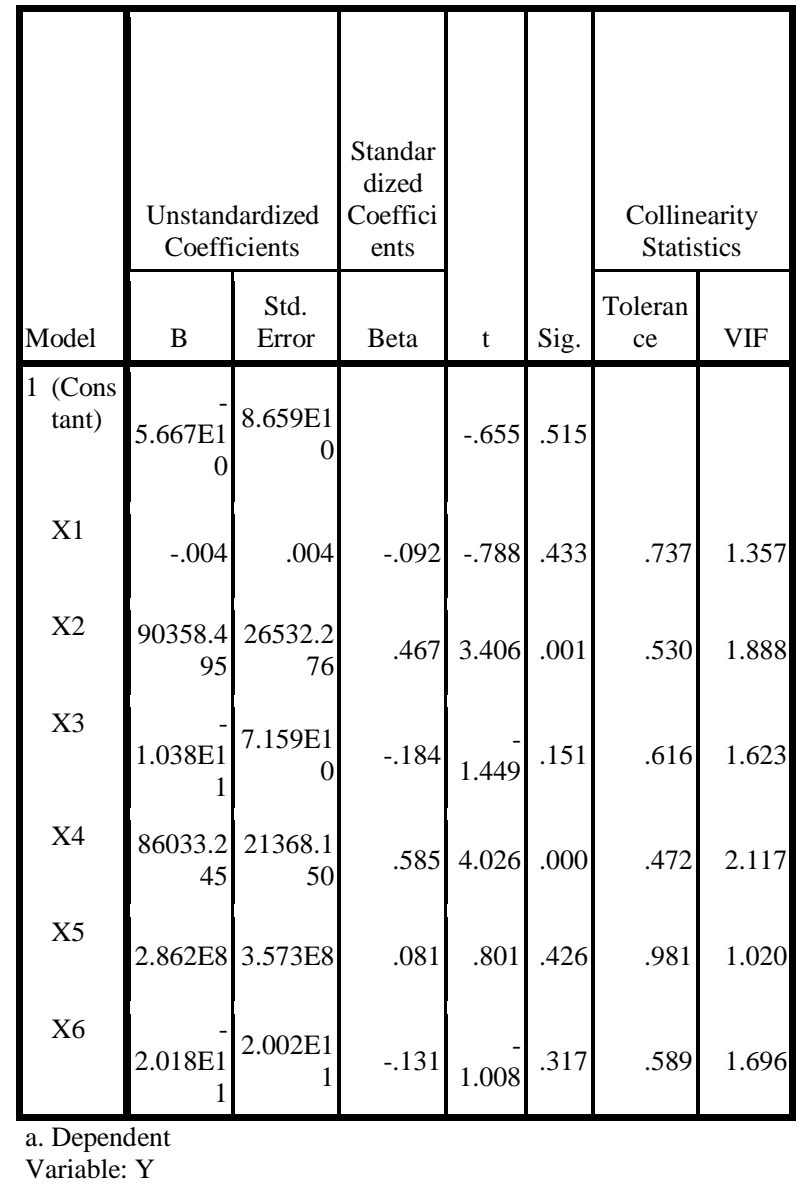

Hasil uji signifikansi menunjukkan bahwa hanya satu variabel karakteristik pemerintah daerah yaitu variabel Kekayaan Daerah $\left(\mathrm{X}_{2}\right)$, dan satu variabel kompleksitas pemerintahan yaitu variabel Jumlah Penduduk $\left(\mathrm{X}_{4}\right)$ secara parsial berpengaruh terhadap Kinerja Fiskal (KF), karena nilai signifikansi jauh dibawah 0,05 atau 5\%. Sedangkan variabel selain kekayaan daerah dan jumlah penduduk secara parsial atau individual tidak berpengaruh terhadap Kinerja Fiskal (KF) karena nilai signifikansinya jauh diatas $5 \%$.

3) PengujianSimultan(UjiStatistikF)

Uji statistik $F$ pada dasarnya menunjukkan apakah semua variabel independen yang dmasukkan dalam model mempunyai pengaruh secara bersama-samaterhadapvariabeldependen (Ghozali, 2006) ${ }^{[14]}$. Hipotesisnol (Ho) yang hendak diuji adalah apakah semua 
parameter dalam model sama dengan nol, atau:Ho:b1 $=\mathrm{b} 2=\ldots \ldots \ldots=\mathrm{bk}=0$.

Hipotesisal ternatifnya (HA) tidak semua parameter secaras imultan sama dengan nol, atau:HA: $\mathrm{b} 1 \neq \mathrm{b} 2 \neq \ldots \ldots \ldots \neq \mathrm{bk} \neq 0$

Tabel 3. Anova (Uji Signifikansi F)

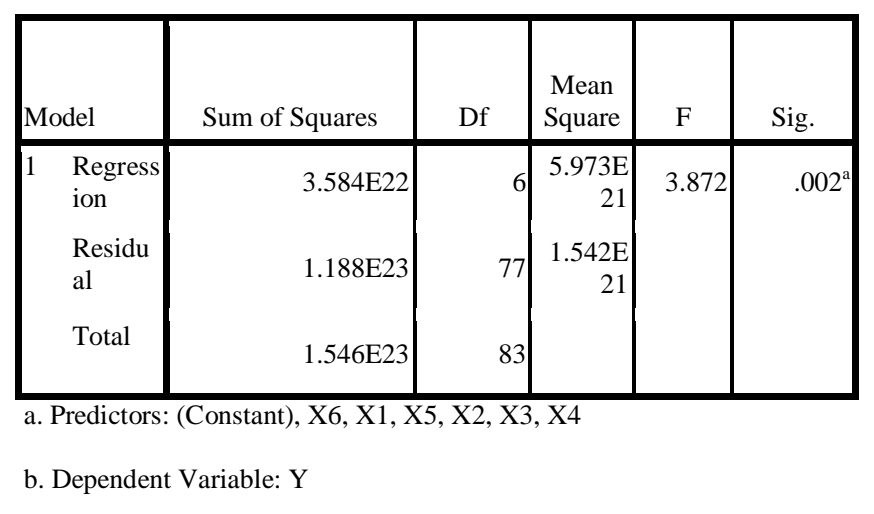

Hasil uji Anova menunjukkan bahwa nilai $F$ hitung sebesar 3,872 dengan probabilitas 0,002 . Karena nilai probabilitas jauh lebih kecil dari 0,05 atau dibawah 5\%, maka model regresi dapat digunakan untuk memprediksi Kinerja Fiskal (KF) atau dapat dikatakan bahwa variabel Ukuran Pemda $\left(\mathrm{X}_{1}\right)$,Kekayaan Daerah $\left(\mathrm{X}_{2}\right)$, Tingkat Ketergantungan $\left(\mathrm{X}_{3}\right)$, Jumlah Penduduk $\left(\mathrm{X}_{4}\right)$, Jumlah SKPD $\left(\mathrm{X}_{5}\right)$, dan Kemandirian Keuangan Daerah $\left(\mathrm{X}_{6}\right)$ secara bersama - sama berpengaruh terhadap Kinerja Fiskal (KF).

B. Pembahasan

Kinerja fiskal/ keuangan pemerintah daerah menggambarkan bagaimana sebuah pemerintah daerah dapat menunjukkan capaian-capaian tujuan finansial yang telah ditetapkan. Menurut Sularso dan Restianto $(2011)^{[15]}$, kinerja keuangan adalah suatu ukuran kinerja yang menggunakan indikator keuangan. Analisis kinerja keuangan pada dasarnya dilakukan untuk menilai kinerja masa lalu dengan melakukan berbagai analisis sehingga diperoleh posisi keuangan yang mewakili realitas entitas dan potensipotensi kinerja yang akan berlanjut. Menurut Halim (2007) ${ }^{[14]}$, salah satu pengukuran kinerja fiskal/keuangan pemerintah daerah dapat dilakukan dengan analisis surplus/defisit.
Pengujian parsial dalam penelitian ini menggunakan uji t dilakukan terhadap variabel independen, apakah berpengaruh secara parsial terhadap variabel dependen. Uji signifikansi $t$ yang dilakukan menunjukkan bahwa dari keenam variabel independen hanya variabel Kekayaan Daerah $\left(\mathrm{X}_{2}\right)$ dan Jumlah Penduduk $\left(\mathrm{X}_{4}\right)$ yang secara parsial berpengaruh terhadap variabel dependen Kinerja Fiskal (KF), karena nilai signifikansi dibawah 0,05 atau $5 \%$. Sedangkan variabel independen seperti: Ukuran Pemda $\left(\mathrm{X}_{1}\right)$, Tingkat Ketergantungan $\left(\mathrm{X}_{3}\right)$, Jumlah SKPD $\left(\mathrm{X}_{5}\right)$, dan Kemandirian Keuangan Daerah $\left(\mathrm{X}_{6}\right)$ tidak berpengaruh secara parsial terhadap Kinerja Fiskal (KF) pemerintah kabupaten/kota di Jawa Tengah.

Uji parsial (uji t) tersebut menunjukkan bahwa kinerja fiskal pemerintah daerah dipengaruhi oleh kekayaan daerah dan jumlah penduduk. Kekayaan daerah yang merupakan bagian dari karakteristik pemerintah daerah, mencerminkan kemampuan setiap penduduk pada kabupaten/kota menikmati pendapatan yang diperoleh pemerintah kabupaten/kota. Semakin tinggi serapan anggaran yang ada di kabupaten/kota maka semakin tinggi kekayaan daerah/pendapatan yang dapat dinikmati oleh masyarakat pada daerah tersebut. Sedangkan jumlah penduduk yang merupakan bagian dari kompleksitas pemerintahan berpengaruh kepada kinerja fiskal daerah artinya bahwa semakin besar jumlah penduduk yang ada pada kabupaten/kota di Jawa Tengah maka semakin tinggi kinerja keuangan daerah yang ada di kabupaten/kota di Propinsi Jawa Tengah, karena semakin besar serapan/realisasi anggaran sehingga tidak terjadi surplus/defisit anggaran yang berlebihan. Surplus anggaran di pemerintah daerah diartikan bahwa daerah tersebut sedang melakukan penghematan anggaran atau kurang optimalnya penyerapan anggaran, sedangkan defisit anggaran bisa diartikan bahwa daerah tersebut membelanjakan utang untuk menutup defisitnya, apabila 
daerah tidak dapat menutup utangnya dapat menimbulkan resiko kebangkrutan (Firmansyah, 2014) $^{[3]}$.

Hasil pengujian parsial ini mendukung penelitian yang dilakukan oleh Mustikarini dan Debby Fitriasari $(2012)^{[4]}$, yang menganalisis pengaruh karakteristik pemerintah daerah dan temuan audit BPK terhadap kinerja keuangan pemerintah daerah kabupaten/kota di Indonesia. Variabel karakteristik pemeritnah daerah meliputi: ukuran pemda, kekayaan daerah, tingkat ketergantungan dan belanja daerah. Hasil dari penelitian ini membuktikan bahwa semua variabel karakteristik pemda dan juga temuan audit BPK berpengaruh signifikan terhadap variabel kinerja keuangan pemerintah daerah kecuali untuk variabel belanja daerah.

Kemudian pengujian yang terakhir adalah pengujian simultan. Hasil uji Anova menunjukkan bahwa nilai $F$ hitung sebesar 3,872 dengan probabilitas 0,002 . Karena nilai probabilitas jauh lebih kecil dari 0,05 atau dibawah 5\%, maka model regresi dapat digunakan untuk memprediksi Kinerja Fiskal (KF) atau dapat dikatakan bahwa variabel karakteristik pemerintah daerah, kompleksitas pemerintahan dan kemandirian keuangan daerah secara bersama - sama berpengaruh terhadap Kinerja Fiskal (KF). Hasil ini menunjukkan bahwa hipotesis yang menyatakan terdapat pengaruh secara simultan variabel Ukuran Pemda $\left(\mathrm{X}_{1}\right)$,Kekayaan Daerah $\left(\mathrm{X}_{2}\right)$, Tingkat Ketergantungan $\left(\mathrm{X}_{3}\right)$, Jumlah Penduduk $\left(\mathrm{X}_{4}\right)$, Jumlah SKPD $\left(\mathrm{X}_{5}\right)$, dan Kemandirian Keuangan Daerah $\left(\mathrm{X}_{6}\right)$ terhadap kinerja fiskal (KF) dapat diterima.

\section{Kesimpulan}

Hasil koefisien regresi menunjukkan besarnya adjusted $\mathrm{R}^{2}$ adalah 0,172 atau $17,2 \%$. Hal ini berarti bahwa variabel dependen Kinerja Fiskal (KF) dipengaruhi oleh variabel Ukuran Pemda $\left(\mathrm{X}_{1}\right)$,Kekayaan Daerah $\left(\mathrm{X}_{2}\right)$, Tingkat Ketergantungan $\left(\mathrm{X}_{3}\right)$, Jumlah Penduduk $\left(\mathrm{X}_{4}\right)$, Jumlah SKPD $\left(\mathrm{X}_{5}\right)$, dan Kemandirian Keuangan Daerah $\left(\mathrm{X}_{6}\right)$ sebesar 17,2\%, sedangkan sebesar 82,8\% dipengaruhi oleh variabel-variabel lain selain keenam variabel independen tersebut.

a) Hasil uji signifikansi menunjukkan bahwa hanya satu variabel karakteristik pemerintah daerah yaitu variabel Kekayaan Daerah $\left(\mathrm{X}_{2}\right)$, dan satu variabel kompleksitas pemerintahan yaitu Jumlah Penduduk $\left(\mathrm{X}_{4}\right)$ yang secara parsial berpengaruh terhadap Kinerja Fiskal $(\mathrm{KF})$, karena nilai signifikansi jauh dibawah 0,05 atau 5\%. Sedangkan variabel selain kekayaan daerah dan jumlah penduduk secara parsial atau individual tidak berpengaruh ke Kinerja Fiskal (KF) karena nilai signifikansinya jauh diatas $5 \%$.

b) Hasil analisis regresi menunjukkan bahwa secara simultan variabel Ukuran Pemda $\left(\mathrm{X}_{1}\right)$,Kekayaan Daerah $\left(\mathrm{X}_{2}\right)$, Tingkat Ketergantungan $\left(\mathrm{X}_{3}\right)$, Jumlah Penduduk $\left(\mathrm{X}_{4}\right)$, Jumlah SKPD $\left(\mathrm{X}_{5}\right)$, dan Kemandirian Keuangan Daerah $\left(\mathrm{X}_{6}\right)$ berpengaruh terhadap Kinerja Fiskal (KF) pada pemerintah Kabupaten/Kota di Propinsi Jawa Tengah. Hal ini dibuktikan nilai $\mathrm{F}$ hitung sebesar 3,872 dengan probabilitas 0,002 .

\section{Daftar Pustaka}

[1] Mahmudi. 2011. AkuntansiSektorPublik.CetakanPert ama. UII Press. Yogyakarta.

[2] Halim, Abdul, 2008, Akuntansi Keuangan Daerah. Edisi Ketiga, Salemba Empat, Jakarta.

[3] Firmansyah. 2014. Perkembangan Ekonomi Kabupaten/Kota dan Kinerja Keuangan Daerah di Jawa Tengah Pada Era Otonomi. JBE. Maret 2014. Vol 21 No.1. FEB. Undip. Semarang.

[4] Mustikarini, WidyaAstutidan Debby Fitriasari. 2012. PengaruhKarakteristikPemerintah Daerah danTemuan Audit BPK TerhadapKinerjaPemerintah Daerah Kabupaten/Kota Di Indonesia TahunAnggaran 2007.SimposiumNasionalAkuntansi ke XIV. Banjarmasin. 
[5] Sumarjo, Hendro. (2010). Pengaruh Karakteristik Pemerintah Daerah Terhadap Kinerja Keuangan Pemerintah Daerah Studi Empiris Pada Pemerintah Daerah Kabupaten/Kota Di Indonesia. Skripsi Sarjana. Universitas Sebelas Maret. Surakarta.

[6] Lin, Ming-lan., Lee, Yuan-Duen., Ho, Tsai-Neng. (2010). Applying integrated DEA/AHP to evaluate the economic performance of local governments in China. European Journal of Operational Research, 209 (2011) 129-140.

[7] Ingram, Robert W. (1984). Economics Incentives and the Choice of StateGovernment Accounting Practices. Journal of Accounting Research. Vol. 22. No. 1. pp 126-144.

[8] Laswad, Fawzi, Fisher, Richard, dan Oyelere, Peter. (2005). Determinants of Voluntary Internet Financial Reporting by Local Government Authorities. Journal of Accounting and Public Policy 24. pp 101-121.

[9] Liestiani, Annisa. (2008). Pengungkapan LKPD Kabupaten/Kota di Indonesia untuk Tahun Anggaran 2006. Skripsi Sarjana. FEUI. Depok.

[10] Hilmi, Amiruddin Zul dan Dwi Martani. 2012. Analisis FaktorFaktor Yang Mempengaruhi Tingkat Pengungkapan Laporan Keuangan Pemerintah Propinsi. Simposium Nasional Akuntansi ke- XIV . Banjarmasi.

[11] Halim, Abdul, 2007, Akuntansi Keuangan Daerah, Penerbit Salemba Empat, Jakarta.

[12] Sugiyono, 2003, Statistika Untuk Peneltian. Cetakan kelima, Bandung: Alfabeta.

[13] Gujarati, D. 2003. Basic Econometric. Mc-Grawhill. New York.

[14] Ghozali, Imam, 2006, Aplikasi Analisis Multivariate dengan Program SPSS, Badan Penerbit UNDIP, Edisi IV, Semarang.

[15] Sularso, Havid dan Yanuar E. Restianto. 2011. Pengaruh Kinerja
Keuangan Terhadap Alokasi Belanja Modal dan Pertumbuhan Ekonomi Kabupaten/Kota di Jawa Tengah. Media Riset Akuntansi. Agustus 2011. Vol. 1. No. 2. FEB. Unsoed. 